Article

\title{
Assessment of Factors Affecting the Amount of Food Waste in Households Run by Polish Women Aware of Well-Being
}

\author{
Jagoda Jungowska, Bartosz Kulczyński, Andrzej Sidor (D) and Anna Gramza-Michałowska *(D) \\ Department of Gastronomy Science and Functional Foods, Faculty of Food Science and Nutrition, Poznań \\ University of Life Sciences, 60-624 Poznań, Poland; jagoda.jungowska@gmail.com (J.J.); \\ bartosz.kulczynski@up.poznan.pl (B.K.); andrzej.sidor@up.poznan.pl (A.S.) \\ * Correspondence: anna.gramza@up.poznan.pl; Tel.: +48-61-848-73-27
}

Citation: Jungowska, J.; Kulczyński, B.; Sidor, A.; Gramza-Michałowska, A. Assessment of Factors Affecting the Amount of Food Waste in Households Run by Polish Women Aware of Well-Being. Sustainability 2021, 13, 976. https://doi.org/ $10.3390 /$ su13020976

Received: 2 December 2020

Accepted: 15 January 2021

Published: 19 January 202

Publisher's Note: MDPI stays neutral with regard to jurisdictional claims in published maps and institutional affiliations.

Copyright: (c) 2021 by the authors. Licensee MDPI, Basel, Switzerland. This article is an open access article distributed under the terms and conditions of the Creative Commons Attribution (CC BY) license (https:/ / creativecommons.org/licenses/by/ $4.0 /)$.
Abstract: Food waste is a pressing problem in Western countries. Increased food waste production directly affects environmental changes and pollution, including greenhouse gas emissions and contamination with packaging. In Poland, 9.2 million tons of food is lost annually, 53\% of which is produced by consumers. To minimize food waste by consumers, it is necessary to understand the factors affecting the behaviors associated with food wasting. This work is focused on investigating the causes and behaviors related to food wasting, and determining the kinds of food that are wasted in Polish households run by women that possess a high awareness of well-being. It was found that most of the respondents who took part in the survey admitted that their households did waste food. It was shown that there is a positive correlation between the number of people living in a household and the amount of food wasted. It was also confirmed that age has an impact on the amount of food discarded by Polish women, because respondents over 37 years of age wasted less food and more often declared a lack of wasting compared to others. In households, fresh food with short expiry dates, including vegetables, fruit, bread, and meat, was wasted the most. The most important factors directly influencing the amount of wasted food were: purchasing too much food, a lack of expiry-date control, a lack of planning of purchases and menus, and a lack of ideas for using food residues. The main element affecting waste is purchasing too much food, most often resulting from susceptibility to promotions, willingness to buy in stock, and a lack of prior planning. Understanding the mechanisms of waste allows households to take actions to effectively reduce it, and therefore ensure greater food security in the world.

Keywords: food waste; consumption; consumers; households; women; zero waste

\section{Introduction}

Every day, millions of people on our planet struggle with hunger, many of whom suffer from severe malnutrition. Despite such depressing data, hundreds of tons of food are wasted every day around the world. It is estimated that one-third (1.3 billion tons) of the food produced globally for consumption ends up in the garbage every year [1]. Improving welfare, the availability and diversity of food, falling prices of products, and rapid development of countries make people pay less attention to not wasting food. The traditional beliefs that were common 30 years ago, with food as a gift to be respected, are now being replaced by ubiquitous consumerism.

Currently, several definitions of food waste are used in scientific literature. Depending on the geographical location, the defining authority, and the stage at which food is lost, different definitions are used. According to the FAO (Food and Agriculture Organization of the United Nations), food waste encompasses three separate issues [2]. Food loss (FL) refers to the reduction in weight (dry matter) or nutritional value (quality) of food that was originally intended for human consumption. These losses are mainly due to the inefficiency of food-supply chains. Food waste (FW) is food suitable for human consumption that is 
thrown away, regardless of whether it has expired or gone bad. This may be due to reasons such as oversupply, a lack of sales markets, or individual consumer decisions, including excessive or unplanned purchases. Food wastage refers to any food lost as a result of spoiling or throwing away. The difference between loss and waste depends on the stage of the food chain at which it is disposed.

On the official website of the United States Environmental Protection Agency (EPA), slightly different terms for food waste can be found. There, a term such as wasted food is distinguished to describe food that has not been used for its intended purpose, but is consumed in many other ways [3]; e.g., it is intended as a donation to feed people in need, to produce animal feed, to compost, to transport to landfills, or to incinerate. Such food includes unsold food from retail stores; post-consumer waste; prepared but uneaten food; kitchen peelings from canteens, hotels, restaurants and households; and byproducts from food and beverage processing plants. The EPA uses the overriding term "wasted food" instead of "food waste" to refer to food that has not been used for its intended purpose, but can be further used as a valuable resource.

In 2017, the Australian government, as part of the "National food waste strategy-halving Australia's food waste by 2030" project, determined that food waste includes solid or liquid food for human consumption (the waste is generated throughout the supply chain and consumption without further subdivision); food that does not reach the consumer or reaches the consumer but is discarded (this includes edible parts, parts that can be consumed but are disposed of, those that are unfit for consumption, or those considered undesirable, such as seeds, grounds, bones, peelings or skins); and food that is imported and disposed of in Australia, or produced for export, but that has not left the country [4].

The European project FUSIONS (Food Use for Social Innovation by Optimizing Waste Prevention Strategies) developed and presented a new definition of food waste. It defines food waste as any food and inedible parts thereof that are removed from the food supply chain for recovery or storage. Recovery may involve composting, bioenergy production, incineration, disposal in the sea, ploughing, or not harvesting [5]. In a resolution by the European Parliament on 19 January 2012, on how to avoid food wastage and strategies for a more efficient food chain in the European Union, food wastage was defined as food eliminated from the agri-food chain for aesthetic or economic reasons or due to expiration that is still fit for consumption, but in the absence of an alternative use, is destined for disposal, with negative environmental and economic consequences. In this resolution, the European Union additionally indicated the negative effects and consequences of wasting food [6]. In turn, according to the report "Food Waste in Poland and Europe", issued by the Federation of Polish Food Banks and the Council for Rational Use of Food of 2012, losses and food waste are defined as follows: food waste and losses are all unprocessed and processed food products fit for human consumption that have been produced but not used [7]. This means that they were not used as intended. This applies to all stages of the food chain, from primary production to consumption. In addition, this report distinguishes three types of weight reduction of food intended for consumption. The term "natural loss" means a reduction in weight of the edible part of a food due to biochemical and physical changes (e.g., by drying), resulting from storage conditions. "Loss" is a reduction in edible food weight resulting from mismanagement, errors, and process irregularities, e.g., in agricultural production during harvesting. "Waste" is a reduction in edible food weight caused by improper distribution, storage, transport, and preparation for consumption in households or food courts.

Based on the above literature data, there is currently no rigid definition of food wastage. It should be noted that there are major inconsistencies with regard to the terms "food waste" and "food wastage", and many organizations and legal entities have their own definitions.

Food loss is a major problem in developed countries. It is observed at all stages of the food chain: during production, distribution, large-scale retail trade and consumption [8-11]. In the catering and hotel sectors, both food-preparation workers and consumers are re- 
sponsible for losses. The waste of meals and food in places such as schools, kindergartens, canteens, gas stations, bars, restaurants, diners, and hotels is also problematic [12,13]. Such behavior is associated with significant economic and ecological losses. Increased overproduction and wastage is associated with an increased amount of garbage produced, animal-husbandry pollution, water loss, and climate change. The phenomenon of food waste affects many dimensions, from environmental and economic to moral aspects. Reducing food waste could increase global food security and reduce environmental risks and financial losses.

Ecological and economic effects are the most significant consequences of losing huge amounts of food products. Negative consequences that directly affecting the environment include increased production of greenhouse gases, waste of water, and pollution by inorganic packaging, which is mainly made of plastic and its derivatives. The entire food chain, from the farmer to the consumer, contributes to the production of greenhouse gases [6,14-18].

A threat of irrational consumerism and food waste is the growing plastic pollution of the whole world. Much of the waste, especially disposable packaging, ends up in the oceans. Swallowing plastic can cause physical damage or blockage of the gastrointestinal tract, which can lead to hunger, infection, and even death of marine fauna. Compounds such as dichlorodiphenyltrichloroethane (DDT) and polychlorinated biphenyls (PCBs) present in plastic waste contaminate fish, which are then directly used as food for humans. Plastic as food waste is a major threat to many marine ecosystems and animals. An increasing number of studies have indicated the content of micro and nano-plastic in fish and seafood consumed by humans. This contamination is not indifferent to human health [19].

Apart from its negative impacts on the environment, food waste causes significant financial losses, both for individual consumers and for the national economy. It is impossible to indicate the amount of total economic losses generated by wasting food. The FAO estimates that global wastage in the entire food chain is USD 2.6 trillion a year. The Waste and Resources Action Programme (WRAP) has estimated that in the United Kingdom, the estimated total amount of food waste is about 10 million tons per year, $70 \%$ of which could have been avoided [20]. According to the data provided by FUSION, the costs associated with food waste in the European Union in 2012 were estimated at about EUR 143 billion, of which $2 / 3$ of the costs were associated with food waste in households [21]. Poland is ranked fifth among EU countries in terms of the highest estimated amount of wasted food. The cost of wastage by Poles is estimated at approximately EUR 14 billion. The president of the Federation of Polish Food Banks stated that a four-person household can lose up to EUR 560 a year by throwing food away [22].

A broad economic impact on consumers may also result from rising food prices [21,23]. The general public's consent to food waste influences young people, who could learn harmful patterns of behavior they will follow in the future. The consumer must be aware that reducing food waste is an important instrument to achieve global food security. Reducing food waste could reduce irreversible damage to the environment.

\section{Literature Review}

According to a European Statistical Recovery Dashboard (EUROSTAT) report, 9 million tons of food are wasted annually in Poland, compared to 7.3 million tons in the UK. It has been shown that in Poland, there are $236 \mathrm{~kg}$ of wasted food per person per year, which puts Poland fifth on the list of European countries in terms of wasted food, following the Netherlands (556 kg/pax), Belgium (370 kg/pax), Cyprus ( $269 \mathrm{~kg} /$ pax) and Estonia (269 kg/pax). Other data from 2017 even say about $247 \mathrm{~kg}$ of wasted food per person in our country $[22,24,25]$. It is estimated that households are responsible for the largest percentage of food wasted in Europe (53\% of total food wasted), followed by processing $(19 \%)$, catering $(12 \%)$, agriculture $(11 \%)$, and the commercial sector $(5 \%)$ [26].

The amount of food wasted in households largely depends on the area, income, household size, and culture. According to a 2018 report by the Federation of Polish 
Food Banks, $42 \%$ of Poles declared food wastage. A study by Bilska et al. [27] showed that up to $62 \%$ of respondents throw away food. The most wasted products are bread, vegetables, yogurt, fruit, and cold cuts. For comparison, in the research conducted by Silvennoinen et al. [28], the main products wasted in Finland are vegetables (19\%), food prepared at home $(18 \%)$, and dairy products (17\%). According to data presented on the official website of the European Commission, households in the EU produce about $35.3 \mathrm{~kg}$ of waste from fresh fruit and vegetables per person per year, of which almost half $(14.2 \mathrm{~kg})$ could be avoided. The WRAP report from 2015 showed that Great Britain annually wastes $77 \mathrm{~kg} /$ pax in households, while Denmark wastes $41 \mathrm{~kg} /$ pax [29]. Unfortunately, there is currently a lack of precise data on the amount of food waste in households in Poland. This subject requires further research [22,27,28,30,31]. Pocol et al. assessed the behavior of households in Romania regarding food waste, and identified three distinct clusters of consumers labeled as careless, precautious, and ignorant [32]. Among those groups, those deemed careless or ignorant were the ones to throw away food. Moreover, they also did not consider food waste to be an issue in terms of environmental, economic, and social impacts. It was also found that neither the level of income nor the environment of residence or education influenced the adoption of anti-waste behaviors. An important element of research is to confirm that women's behavior when buying food is different from that of men, and leads to less food waste [33]. Other studies have shown that women are more conscious and cautious when shopping, and waste less food when their education ends at age 15 [34]. It was also found that small-town and city residents waste more food than those in rural areas [34-36]. Research by Cantaragiu found that women tend to be more concerned about the negative impact of food waste on the family budget or social equity [37]. Furthermore, they were found to display behaviors in regard to buying and preparing food that result in higher food waste in a larger degree than men. According to the FAO, there is compelling evidence of the fundamental role of women in food value chains. In the agricultural sector, women comprise around $43 \%$ of the workforce worldwide, playing a primary role in production and post-harvest activities [38]. Furthermore, women often combine food-production activities with care and household tasks, creating time and energy constraints that can significantly influence food loss.

For many years, traditions and the political system in Poland required that Polish women buy food and run households. As a result, reducing food waste and its processing has become a permanent part of their mentality. Today, awareness among Polish women is growing, and they implement many pro-ecological behaviors that can significantly reduce food waste and financial losses. Indeed, the motivations and barriers have already been investigated, but our goal was to determine whether a selected group of women would be subject to the same factors found in the other studies. Therefore, the aim of the study was to analyze the essence of the phenomenon of wasting food in Polish households run by women that possess a high awareness of well-being. The aim is to analyze and present the determinants of food wastage, to identify the causes of this phenomenon and the social behaviors that accompany it, to compare the causes and stimuli that play a role in food wastage, and to assess the types of food that are thrown away. Based on the presented definitions, it was decided to use the term developed by the FAO, which separates the terms "food waste" and "food loss" [39]. The term "food waste" is consistent with the subject here, which refers directly to food waste in households.

\section{Materials and Methods}

\subsection{Study Design}

Women are traditionally responsible for the purchase and preparation of food in Poland, so the emphasis of this research was placed on examining women only. The main goal of this research was to evaluate factors affecting the amount of food waste by Polish women who possess a high awareness of well-being. Therefore, despite the limitations of the questionnaire tool, it was considered as an appropriate approach at the initial stage of assessing the factors influencing food waste in Polish households. Prior to data collection, 
the questionnaire was pretested with a smaller sample $(N=20)$, using the same method of addressing the respondents as in the final survey. No problems were found, and no changes were required to either the questionnaire or the survey procedure. The survey was conducted using Google Forms as a tool, and the distribution of the link related to the questionnaire was done by the snowball method, via e-mail and social networking. In order to study the factors affecting the amount of food waste in households, a random group of Polish women were surveyed. An online survey research method was completed by women from different social groups, of different ages, living throughout the country. The questionnaires were made available in five Facebook groups: "Food Cooperation Wrocław", "Zero Waste Wrocław", "Soup Lovers—support, dieting, recipes", "Anthropogenic climate and environmental changes", and "Women run". Food Cooperation Wrocław is a group of people willing to buy local, traditional, organic food "directly from the farmer." Zero Waste Wroclaw gathers people interested in the reduction of waste production in households. The Soup Lovers group consisted mainly of women aged 40+ who were trying to reduce their body weight with a diet based on meals in the form of soups. The Anthropogenic group consisted of people interested in environmental protection, climate change, and human impact on ecosystems. The "Women run" group included women of all ages who run for pleasure or recreation. The target group for the research was only women, whose participation in the survey allowed the collection of 446 questionnaires.

\subsection{Data Collection}

The research was carried out in February and March 2019. In order to improve the quality of data collection, the questionnaire was pre-tested on a small sample of respondents. The questionnaire was implemented online, A total of 500 responses was collected. These raw data were examined, and after eliminating the inconsistencies, a sample of 446 valid answers was obtained. The research was carried out using the survey technique with a questionnaire containing closed questions, questions of a single and multiple choice, and scale questions concerning the reason, amount, and frequency of wasting food.

\subsection{Respondents Description}

The survey involved 446 respondents, half of whom were women aged $26-30,19 \%$ of whom were aged $37-45$, and $16 \%$ of which were over 45 years old (Table 1 ). The smallest group (15\%) were women aged 18-25. Respondents lived in urban (87.6\%) and rural areas $(12 \%)$. Regarding the education of the respondents, $75 \%$ had obtained a higher education, and $22 \%$ a secondary education. A small percentage were women with primary and secondary education (3.2\%). The survey also showed that $81 \%$ of the women were professionally active, $9 \%$ were in school, $6 \%$ were unemployed, and $4 \%$ were retired. The family structures of the studied group were mainly a 3-4-person group (41\%), a two-person group $(38 \%)$, or a group of one $(13 \%)$, while the rest declared that they lived in households with more than four people.

\subsection{Statistical Analysis}

Multiple statistical methods were used in this study. To investigate the frequency distributions of the studied demographic variables, frequency distribution tables with relative frequencies were used, displayed as a percentage. The chi-square test of independence in the contingency table was used to test the relationship between two categorical variables. The strength of dependence was estimated using the Pearson contingency coefficient. All the data were analyzed using Statistica software version 13 PL (StatSoft, Kraków, Poland). 
Table 1. The sociodemographic characteristic of survey respondents.

\begin{tabular}{|c|c|c|}
\hline Feature & Characteristics & Share $[\%]$ \\
\hline \multirow{4}{*}{ Age } & $18-25$ & 15 \\
\hline & $26-36$ & 50 \\
\hline & $37-45$ & 19 \\
\hline & Over 45 years old & 16 \\
\hline \multirow{5}{*}{ Place of residence } & Villages & 12 \\
\hline & Cities over 20,000 up to 100,000 inhabitants & 14 \\
\hline & Cities over 100,000 up to 250,000 inhabitants & 8 \\
\hline & Cities over 250,000 up to 500,000 inhabitants & 15 \\
\hline & Cities over 500,000 inhabitants & 51 \\
\hline \multirow{4}{*}{ Education level } & Primary & 2 \\
\hline & Vocational & 1 \\
\hline & Secondary & 22 \\
\hline & University & 75 \\
\hline \multirow{4}{*}{ Employment } & Student & 9 \\
\hline & Employed & 81 \\
\hline & Unemployed & 6 \\
\hline & Pensioner & 4 \\
\hline \multirow{4}{*}{$\begin{array}{l}\text { Number of people in the } \\
\text { household }\end{array}$} & One & 13 \\
\hline & Two & 38 \\
\hline & Three-four & 41 \\
\hline & Over four & 8 \\
\hline \multirow{5}{*}{$\begin{array}{l}\text { Monthly net income per } \\
\text { person in the household } \\
\text { (EURO) }\end{array}$} & Below 235 & 9 \\
\hline & $236-350$ & 31 \\
\hline & $351-820$ & 28 \\
\hline & 821-1050 & 14 \\
\hline & Above 1051 & 18 \\
\hline
\end{tabular}

\section{Results and Discussion}

\subsection{Survey Results}

The first question was about understanding the concept of food waste (Figure 1). The most frequently chosen answer was: "Throwing away all kinds of food" (38\% of responses). The next most frequently chosen answer was: "Consciously or unconsciously, causing a loss of the properties of food, which results in its disposal" (33\%). The answers: "Throwing away any food purchased in excess", "Throwing away food suitable for consumption (e.g., withered, dried)", or "Throwing away food unfit for consumption (e.g., spoiled, expired)" were each chosen by $8 \%$ of the respondents.

Almost half (47\%) of the respondents declared that they waste food; $23 \%$ would rather waste, and $28 \%$ would rather not. Only $2 \%$ of respondents declared that they do not waste food. According to a 2018 report by the Federation of Polish Food Banks, $42 \%$ of the population admit to wasting, 55\% believe that they do not waste, and $2 \%$ do not remember [22]. At the beginning of the second decade of this century, food waste was declared by far fewer people, with $24 \%$ in $2011,30 \%$ in 2012, and $39 \%$ in 2013 . According to the research carried out by Bilska et al. [27], 62\% of respondents stated that they happen to throw food away, 1/3 of respondents sometimes threw food away, and $9 \%$ did not waste food at all. It should be emphasized that men and women took part in the above-mentioned research. In the study of Elmenofi et al., it was shown that in Egypt, 13.8\% of respondents declared that they did not waste food at all [40]. Rohm et al. reported that consumers are responsible for a significant amount of the food wasted, which could be avoided if they were willing to accept the so-called suboptimal sensory characteristics of food that is still edible, but for which the "best before" date is approaching or has passed [41]. It is also not important that the decision to accept or reject such food is made in the store or after buying it in the household. 
Throwing away food that is unfit for consumption

(e.g. spoiled, expired)

Discarding food suitable for consumption (e.g. withered, dried)

Throwing away any food purchased in excess

Consciously or unconsciously, causing a loss of the properties of food, which results in its disposal

Throwing any kind of food

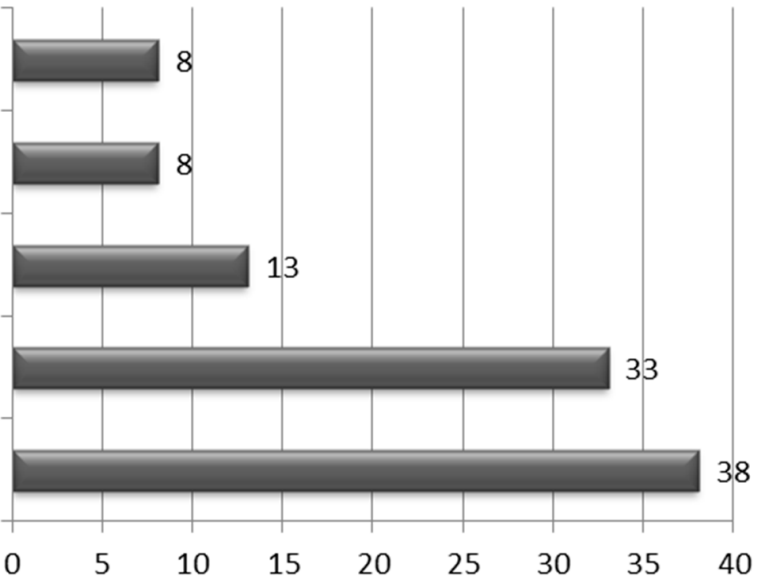

Response rate [\%]

Figure 1. The meaning of the concept of food waste by respondents.

When asked about the last time they wasted food, 30\% of respondents answered that it was in the last three days, $25 \%$ in the last week, $25 \%$ in the last two weeks, and $20 \%$ over a month ago. According to a study comparing food waste by Poles in their homeland and those living in the UK conducted by Skotnicka et al. [42], as many as $18 \%$ of Poles living in their homeland declared that they do not waste food, with over $37 \%$ confirming that they waste occasionally, $27.5 \%$ sometimes, and over $17 \%$ often. In the case of compatriots living in the UK, the waste was as follows: $7 \%$ of respondents do not throw food away at all, $42 \%$ waste occasionally, $34 \%$ sometimes, and $24 \%$ often. According to Quested et al., the behaviors and practices associated with waste production are complex, and usually are performed for reasons unrelated to waste prevention, having both a marked habitual and a pronounced emotional component [43].

The main place where the respondents declared that they most often waste food was home $(93 \%)$, while only $7 \%$ of the women most often did it outside the home. Regarding the reason for wasting food outside the home, more than half of the respondents indicated that the ordered food was unsatisfactory and did not meet their expectations, $22 \%$ do not eat outside at all, $14 \%$ put too much on their plate, and $7 \%$ were ashamed to ask about a take-away packaging (Figure 2). From among the respondents, $6 \%$ answered that the place from which they ordered the food did not have such a packaging.

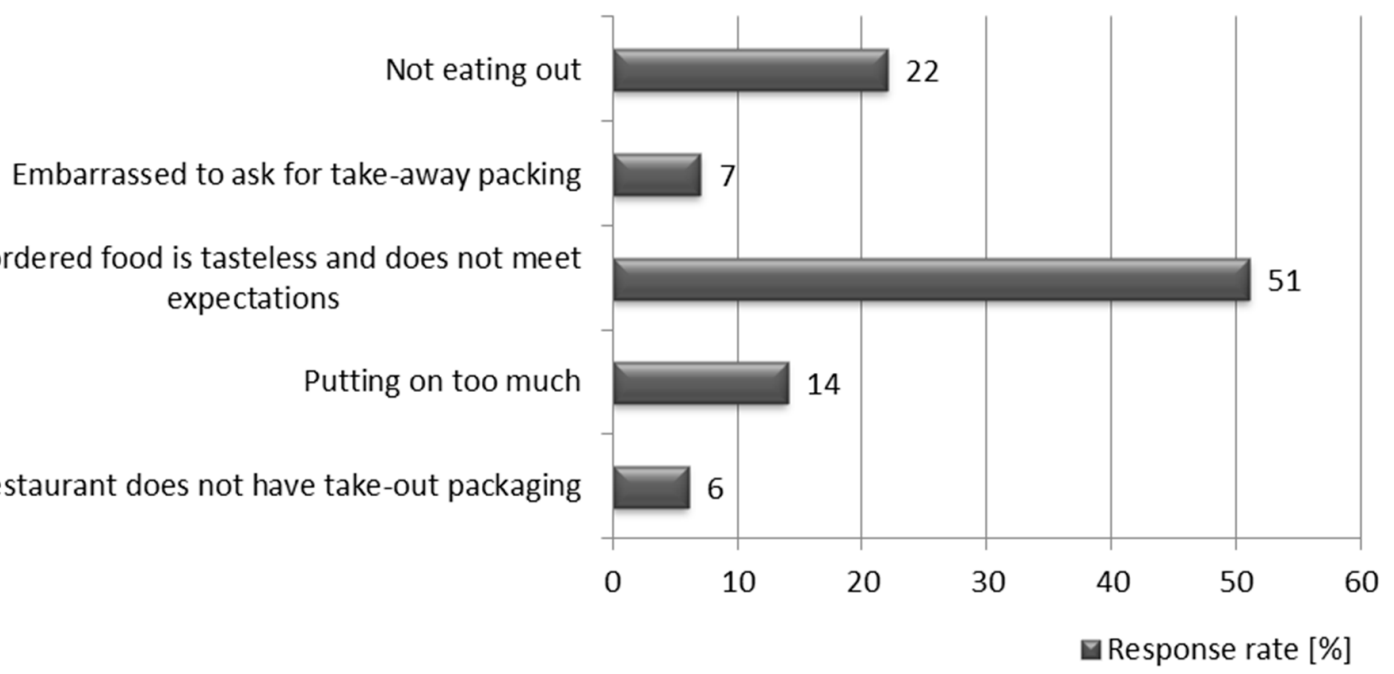

Figure 2. Self-assessment of the respondents regarding the reasons for wasting food during meals outside the home. 
Research shows that there are many factors that cause food waste in households and supply chains. Research by Aschemann-Witzel and her coworkers indicated that management skills of food provisioning and handling, motivation to avoid wastage, and consumers' trade-offs between priorities have a large impact on their food-wasting behaviors [44]. When asked about the factors influencing the amount of wasted food, where it was possible to mark more than one answer, $62 \%$ of the respondents indicated purchasing too much food, $45 \%$ lacked expiry-date control, and 36.2\% lacked prior planning of purchases and menus for several days (Figure 3). Among the surveyed group of women, $35.8 \%$ indicated they had no ideas for using food residues, $29.4 \%$ declared preparing meals that were too large, and as much as $27.4 \%$ declared purchasing a product of inadequate quality. The other answers concerned mental aversion to less-attractive foods (19.4\%), lack of knowledge about whether the food was fit for consumption (6.8\%), and a lack of knowledge about proper food storage (6.6\%). According to research by the Federation of Polish Food Banks, the most frequently mentioned reasons for wasting food were missed expiry date $(29 \%)$, purchases that were too large $(20 \%)$, portions that were too big $(15 \%)$, purchases of poor-quality food (15\%), inappropriate storage $(13 \%)$, lack of ideas for the use of ingredients (5\%), and lack of a shopping list (1\%) [22]. The research conducted by Silvennoinen et al. showed that in Finland, the most important reasons for throwing food away were: spoilage (e.g., mold) 29\%, missed expiration date $19 \%$, and leaving leftovers on the plate $14 \%$ [28]. This study also showed that the waste of vegetables and fruit was associated with inappropriate storage. Other studies indicated that making a shopping list affects other behaviors, leading to less food being thrown away $[34,45,46]$. The research by Farr-Wharton [47] showed that the consumer's knowledge of the quantity and quality of food being stored was the basis for reducing the amount of purchased food and its uncontrolled termination. Findings of Dusoruth and Peterson suggested that people determined acceptability of food based on product attributes in largely the same way, regardless of their food-related aptitude [48].

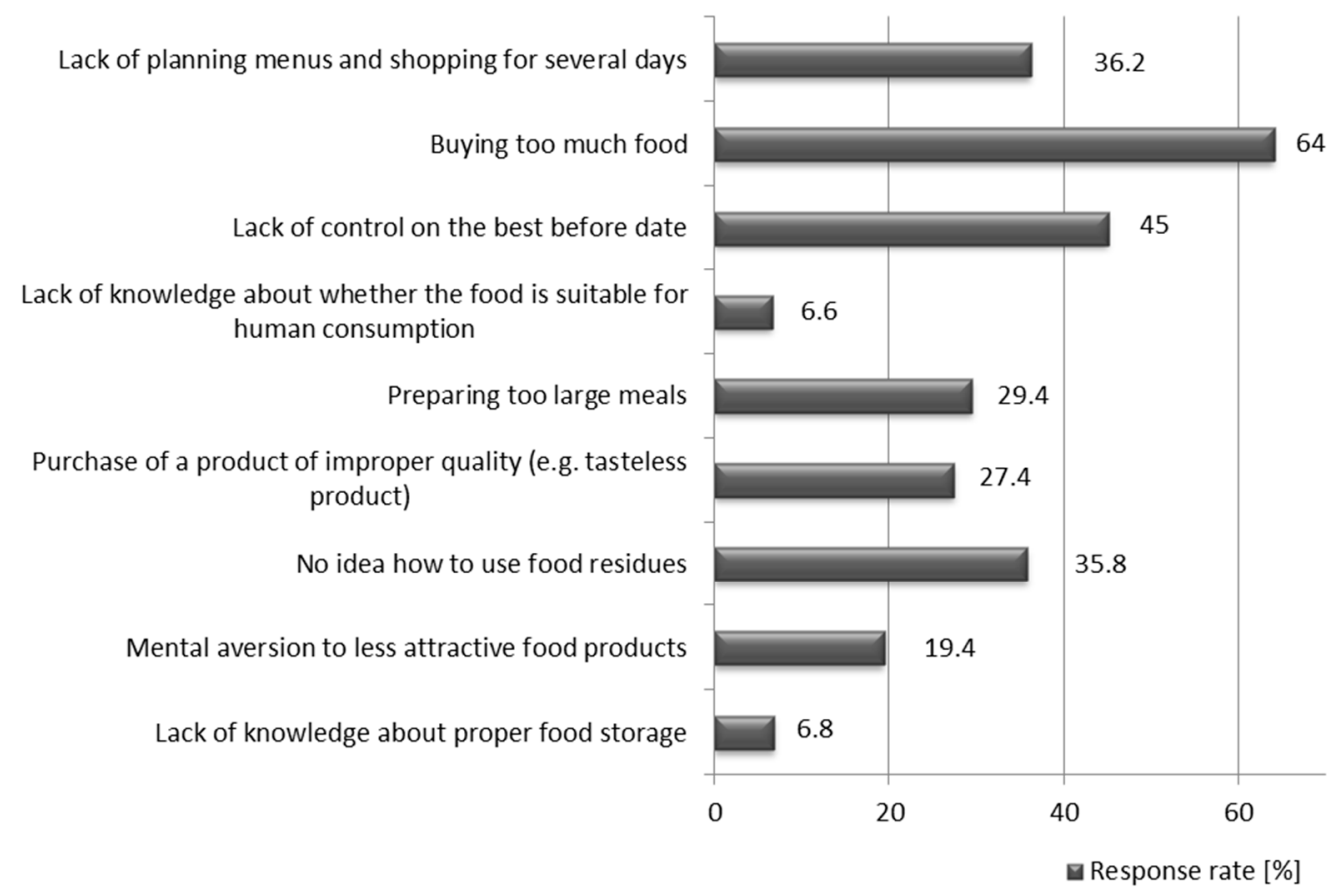

Figure 3. Self-assessment of the respondents regarding factors directly affecting the amount of food wasted in their households (multiple-choice).

More than half of the women surveyed stated that visible mold or a "bad" smell determines whether food products are fit for consumption; $29 \%$ believed that the expiry date indicates suitability; $9 \%$ reject products that are wrinkled, stale, or discolored; and 
$4 \%$ indicated the date of minimum durability on the label as an indicator of suitability (Figure 4). Helmert et al. studied the behavior of eye movements on food items in a purchase-or-discard decision task [49]. Results showed that there has been a decline in purchasing decisions for suboptimal products compared to impeccable products. Beneficial to reducing food waste was the fact that when suboptimal items were presented with differently designed price badges, a positive trend to purchase was obtained. The studies conducted by Yildirim et al. in Turkey showed that there are still some uncertainties about the definition of expiry dates. It was shown that approximately $59.3 \%$ confuse the meaning of "best before" by considering that it means the same as "use by" [50]. Only $39.3 \%$ of respondents correctly stated that food is still safe to eat when it the label says "best before".

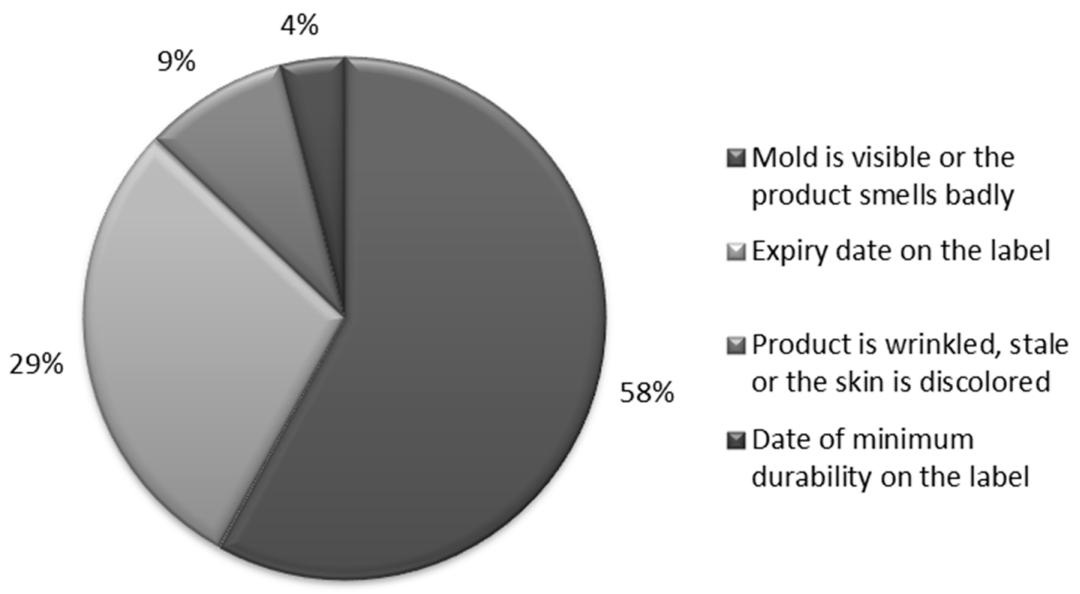

Figure 4. Self-assessment of the respondents regarding the indicators of spoiled food and unsuitability for consumption.

The best-known principle of storage indicated by the women surveyed was not to freeze thawed products again (85.6\%); another principle was to cool food after cooking and store it at a correspondingly lower temperature (78.4\%). The FIFO (first in first out) principle was known to $66 \%$ of respondents (Figure 5). Transferring food products from open packages to appropriate closed containers was indicated by $57.8 \%$ of the respondents, while $51.8 \%$ had encountered the practice of storing food products of various groups on separate shelves in the refrigerator. Only $1.4 \%$ of the respondents stated that they did not encounter any of the rules. According to Fami et al. [51], households whose members have the knowledge and skills to plan and prepare meals waste much less food.

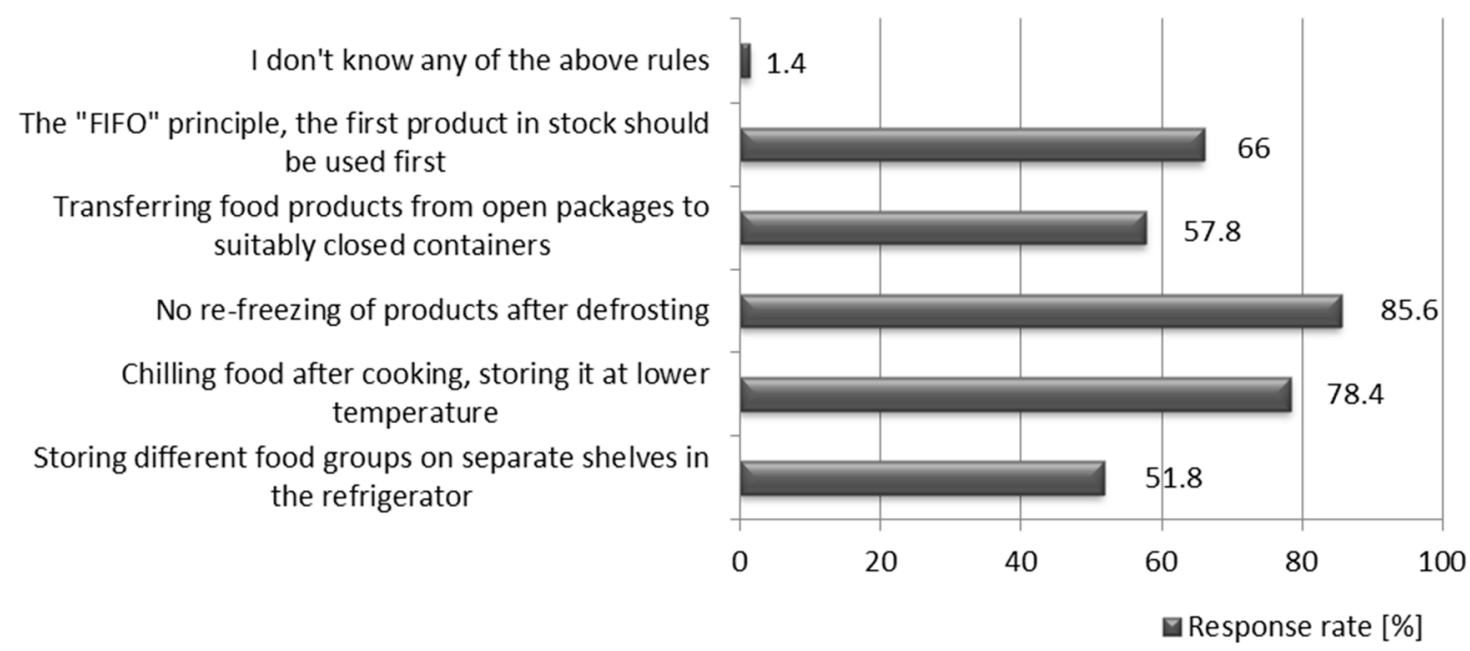

Figure 5. Self-assessment of the respondents regarding their knowledge of the rules of food storage. 
When asked about food-wasting behavior, the majority of respondents, as much as $74 \%$, indicated that none of the answers concerned them. The other respondents indicated that they do not pay attention to wasting food because it is generally available (14\%), that no one in their family has paid attention to wasting food before (9\%), and that they like having a "full fridge" because they can afford it (4\%).

The analysis of the frequency of wasting food products showed that the respondents most often waste bread and confectioneries: 5\% indicated this as "very often", and 9\% "wasted often" (Figure 6). Subsequently, meat products, dairy products, vegetables, and fruit and finished products were characterized by the highest frequency of waste. Dry products $(76 \%)$, eggs (74\%), and snacks and sweets $(59 \%)$ were indicated as non-waste products. It should be emphasized that a large number of respondents indicated a lack of meat $(38 \%)$ and dairy products $(36 \%)$ in their diet. Research by Jörissen et al. conducted among German and Italian households confirmed that the most wasted products are vegetables, fruit, and bread [46]. However, they indicated that the frequency of wasting eggs was not the lowest, as confirmed by a survey among 500 women in Poland. Eggs were indicated right after dairy products and before red meat. The products with the lowest frequency of waste turned out to be salty snacks and oils. The highest percentage, as much as $62 \%$ of respondents indicated that up to $10 \%$ of purchased food is wasted in their household, while none of the women indicated food wastage at a level above $41 \%$. Considering the place of residence, $67 \%$ of the women participating in the survey lived in close proximity to a supermarket (up to $1 \mathrm{~km}$ ), $27 \%$ lived within a distance of 2-5 km, 5\% within 5-15 km, and only 1\% within $15 \mathrm{~km}$. According to the survey, women most often shop at supermarkets and hypermarkets (40\%), 34\% of the respondents choose discount stores, $17 \%$ choose local stores, and 7\% choose markets and bazaars. Only $2 \%$ of respondents indicated organic stores and regional food stores as the most frequent places to buy food. The results of other studies confirmed that in households where purchases are made more often, less food is wasted, which allows for better adaptation to current nutritional needs $[46,52]$.

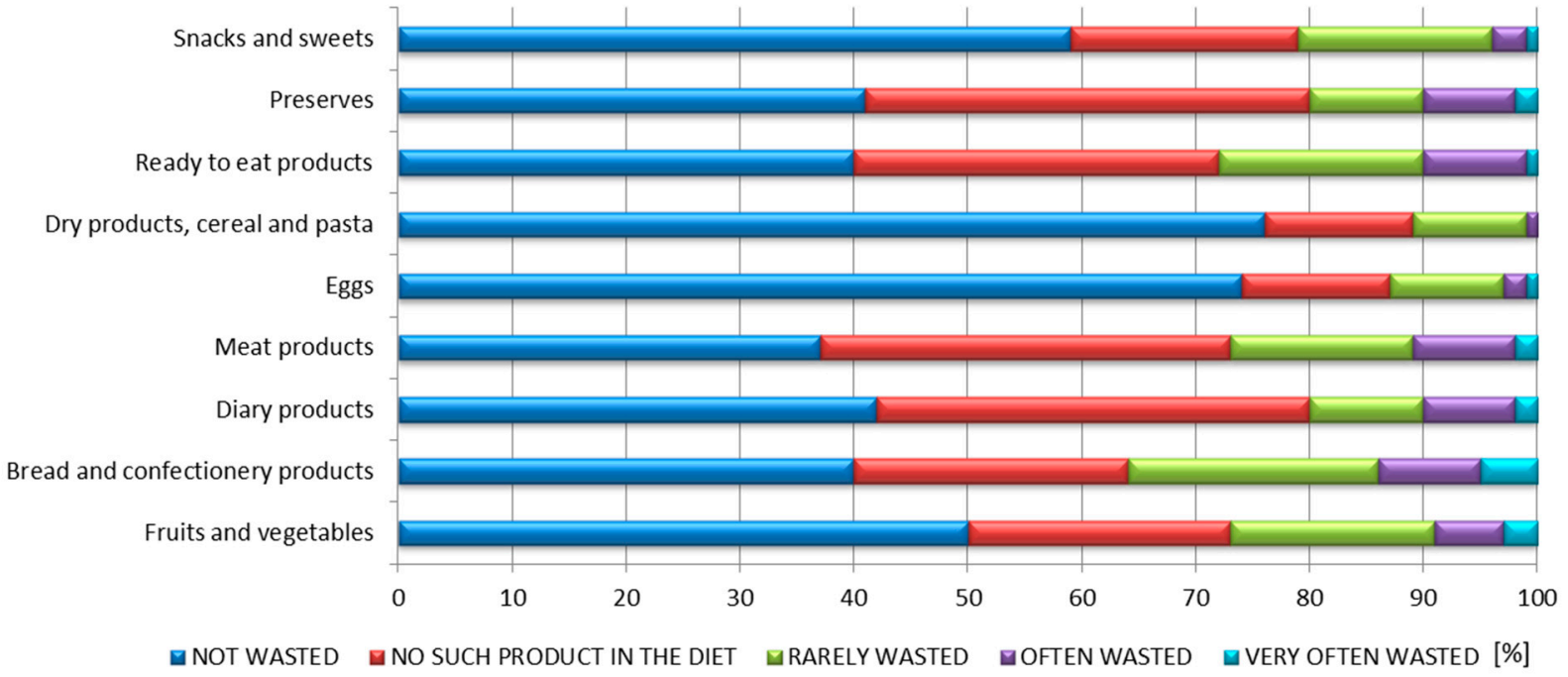

Figure 6. Self-assessment of the respondents regarding their knowledge of what products are most often wasted in their households.

According to almost half of the respondents, the increased purchase of food is mostly influenced by price promotions (reduction of initial prices: $10 \%,-20 \%$, etc.), willingness to buy in stock, and by promotions offering more product $(2+1,2+2$, free products). The lack of prior planning of purchases and the impossibility of purchasing a product in smaller packaging or weight was indicated by $36.8 \%$ of the respondents (Figure 7 ). Over a quarter of the respondents indicated that their volume of food purchases was also affected by the 
fear that one of the products would run out. It should be stressed that in this question, the respondents could indicate more than one answer. As Bilska et al. showed, the purchase during promotions of food with a short expiry date is not popular among Poles [33]. Other studies confirmed that respondents that bought food at regular prices wasted more food for the simple reason that they could afford to buy it again, as opposed to those buying during a promotion $[53,54]$.

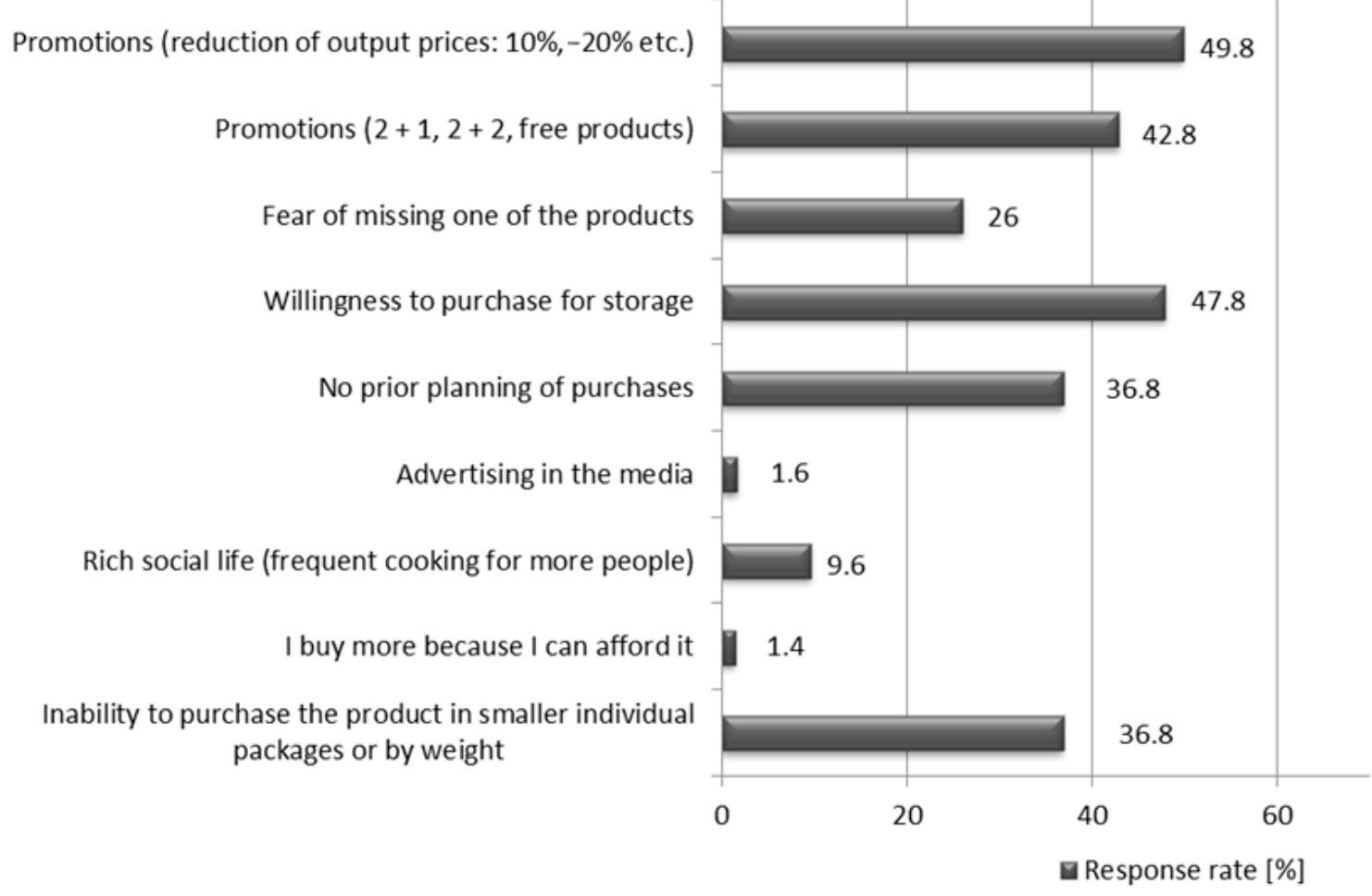

Figure 7. Self-assessment of the respondents regarding factors affecting the purchase of more food products in the household (multiple choice).

When shopping, $60 \%$ of respondents were led by food quality, with price not playing a role; $23 \%$ by the price-to-volume ratio; $14 \%$ by price; and $4 \%$ by the brand and producer (Figure 8). When asked about the period in which food was wasted most in their households, as many as $45 \%$ of women replied that the period does not matter, and that food was wasted evenly throughout the year; $33 \%$ of respondents indicated that food was wasted during holidays or celebrations; $13 \%$ said it was wasted in summer, when temperatures are higher; while as much as $9 \%$ said the most food was wasted before or after vacations. Surveys of Turkish farms have not confirmed that the period does not matter when wasted. According to Yildirim et al. the period of the year affects the amount of waste [50]. The researchers found that the waste increases in the holy month of Ramadan (due to fasting). Williams et al. also indicated that waste is also related to the type of packaging [54]. Bilska, Tomaszewska, and Kołożyn-Krajewska proposed a hierarchy of risks leading to food waste at home, among which the most important were meal spoilage and lack of control over expiry dates [33]. 


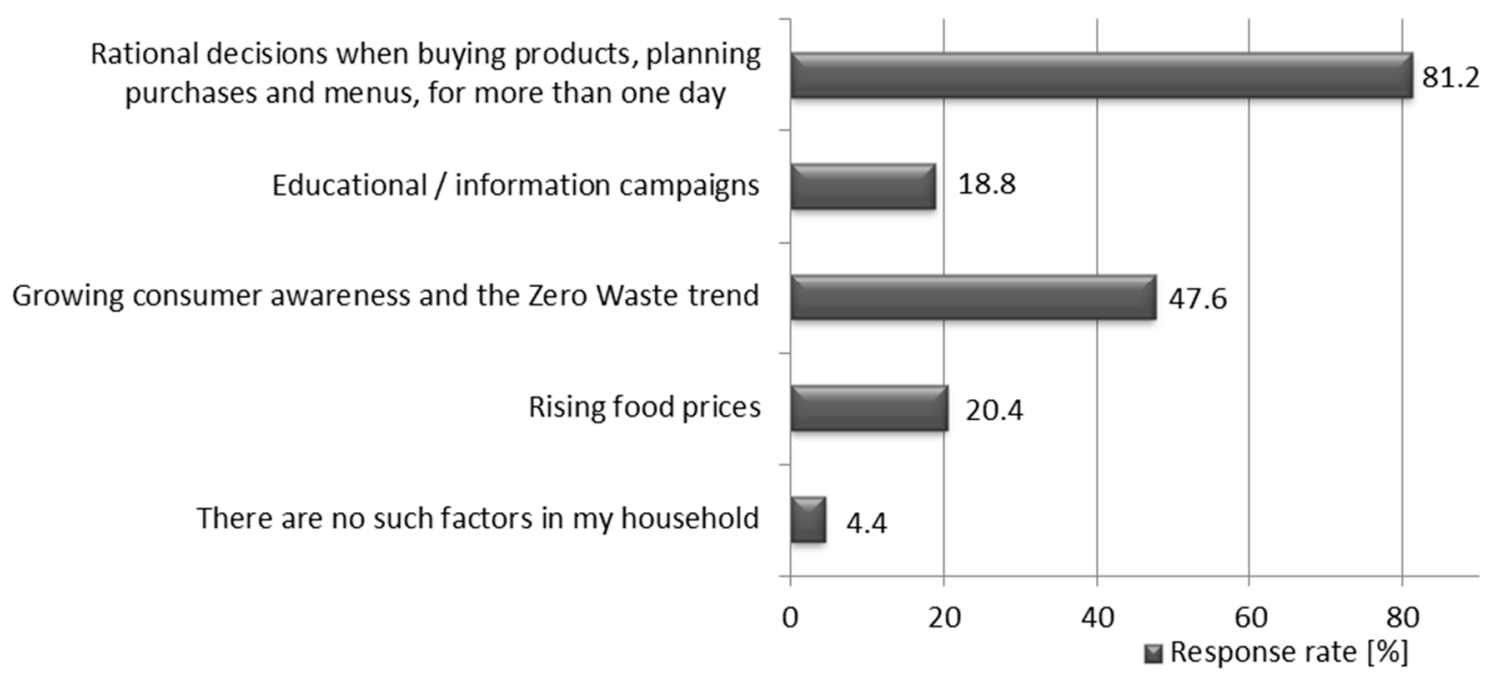

Figure 8. Self-assessment of the respondents regarding factors affecting the reduction rate of food waste.

As a factor reducing the amount of food waste, most women indicated rational decisions when buying products, planning shopping and menus for more than one day $(81.2 \%)$, and $47.6 \%$ chose increasing consumer awareness and the "Zero Waste" trend. Rising food prices were indicated by $20.4 \%$ of respondents, while educational/information campaigns were indicated by $18.8 \%$, and $4.4 \%$ stated that such factors did not occur in their household. It should be stressed that in this question, the respondents could indicate more than one answer. According to a report by the Federation of Polish Food Banks, planning purchases with a list and menus can reduce the amount of waste produced, and educational campaigns are an important tool in the fight against waste [22]. According to Koivupuro et al. [53], food wastage is a result of excess shopping, a lack of control of food in stock, serving portions that are too large, and a lack of ideas regarding how to remake the food. Moreover, the research by Aschemann-Witzel has shown that consumers can accept the price of suboptimal food based on the use-by date by improving quality perceptions, deepening the knowledge of the practice, and providing guidance that will ensure consumers that all food can be used in the household [55].

\subsection{Factors Influencing the Type of Food Waste}

In the next stage of the research, a statistical analysis using the $\chi^{2}$ test was conducted to give answers to a number of specific questions. It was found that in the group of respondents on a vegetarian diet, the answer that identified them with the Zero Waste trend was chosen significantly more often. In the vegetarians group, $63.8 \%$ chose the answer concerning Zero Waste, and in the remaining group, it was $44.5 \%\left(\chi^{2}=9.95 ; p=0.016\right)$. Vegetarians were significantly more likely to correctly determine whether food is fit for consumption $\left(\chi^{2}=21.13 ; p=0.000004\right)$ and define food wastage $\left(\chi^{2}=4.85 ; p=0.027\right)$. When analyzing another group of respondents, it was found that older women (over 45 years old) declared they did not waste significantly more often than the other groups $\left(\chi^{2}=13.16\right.$; $p=0.0002)$. Women from large cities were more likely to buy in stock. For inhabitants of large cities, $50.6 \%$ chose to buy in stock, and among women from villages and small towns, $40.2 \%\left(\chi^{2}=4.20 ; p=0.04\right)$. It was also found that women who waste significantly more often declare their willingness to buy in stock $\left.\chi^{2}=21.43 ; p=0.00004\right)$. The respondents with higher education were significantly more likely to have greater knowledge of proper food storage $\left(\chi^{2}=7.75 ; p=0.005\right)$, which was confirmed in the group associated with the Zero Waste trend. $\left(\chi^{2}=5.54 ; p=0.01\right)$. On the other hand, women who declared that they do not waste significantly more often had greater knowledge about the proper storage of food. In the non-waste group, $63.3 \%$ chose more correct answers, and in the wasting group, $46.2 \%\left(\chi^{2}=12.62 ; p=0.0003\right)$. The respondents who were led by quality when shopping more often had greater knowledge about the proper storage of food $\left(\chi^{2}=10.69\right.$; 
$p=0.001)$, and those related to the Zero Waste trend significantly more often correctly stated whether food was fit for consumption $\left(\chi^{2}=22.18 ; p=0.000002\right)$. Moreover, it was found that the correct definition of food wastage was related to the age of the respondents. Younger women (under 37 years old) were significantly more likely to correctly define food waste than the group above that age $\left(\chi^{2}=9.41 ; p=0.002\right)$. It was surprising that people that declared food waste were significantly more likely to define it correctly $\left(\chi^{2}=6.53\right.$; $p=0.01$ ). Moreover, people with higher education significantly more often choose the Zero Waste trend. In the group of educated people, $50.5 \%$ chose this trend, and in the group of less-educated people, $38.8 \%\left(\chi^{2}=5.12 ; p=0.023\right)$.

\section{Conclusions}

More than 1.3 billion tons of food is wasted and ends up in dumps across the globe every year, of which households account for $53 \%$. Such a large-scale process causes a number of very serious environmental effects and socio-economic damage. The results of our analyses confirmed that food waste is a huge problem and challenge for Polish households run by women who possess a high awareness of well-being. Problems with defining food waste and determining whether food is fit for consumption were demonstrated. Statistical analysis confirmed that socio-demographic variables influenced the amount of food thrown away. Direct factors included the age of the respondents, size of the household, and distance from the store. Older respondents more often declared that they did not waste food and statistically threw away the least amount of food than the others. Other factors were the size of the household and the distance from the store; women who lived in larger households and who lived farther from the store wasted more food. Educated women presented more knowledge about proper storage, but did not waste less food than other respondents.

It was found that knowledge of the rules of proper storage affects the amount of food wasted, with respondents with less knowledge wasting statistically more food. It was shown that the respondents who correctly stated whether the food was fit for consumption wasted the least amount of food, which confirmed the thesis that awareness and knowledge affect the amount of food wasted. The respondents associated with the Zero Waste trend showed greater knowledge of the problem of food waste, as they were significantly more likely to determine their suitability for consumption and have greater knowledge about proper storage. Importantly, following the Zero Waste trend did not, however, reduce wasted food in Polish households. Vegetarians paid more attention to the products they eat, which is due to the elimination of meat products and the closeness to the Zero Waste trend. They gave statistically more correct answers concerning the definition of food waste and the determination of whether food is fit for consumption. As a result, it was confirmed that they showed more thoughtful and conscious consumption.

Elements such as lack of purchase planning and excessive purchases contribute to wasting more food, while proper storage reduces household waste. Our study showed that fresh products, including vegetables, fruit, bread, meat, and fish, are the most likely to be wasted. The results obtained during our research indicated that increasing awareness of the issues related to storage (especially fresh products), making rational decisions during purchases and their planning, and controlling the expiry date are important factors in reducing waste in households.

It should be stressed that a key element in reducing food waste is education on how to store food and how to further use leftovers. Society should be aware of the need to "recycle" food to avoid generating unnecessary waste, which has a negative impact on the environment. Attention should also be paid to promoting the transfer of food to the poor, in the form of a "food-sharing" network, in which everyone has the opportunity to bring food to save it from being wasted and also help those in need. The structure and amount of food waste and the factors influencing them are relatively little studied. More research and analysis is needed to determine their essence more precisely and develop a strategy to reduce food waste. 
Author Contributions: Conceptualization, methodology, formal analysis, investigation, and writing-original, J.J.; formal analysis, writing, review, and editing, B.K.; draft preparation, writing-review and editing, and visualization., A.S.; conceptualization, investigation, writing, editing, supervision, and funding acquisition, A.G.-M. All authors have read and agreed to the published version of the manuscript.

Funding: This research was supported by EcoWaste4Food project co-financed by the European Regional Development Fund (ERDF) under the Interreg Europe Program entitled "Supporting EcoInnovation to Reduce Food Waste and Promote A Better Resource Efficiency Economy (2017-2020)"; and statutory funds of Department of Gastronomy Science and Functional Foods, Poznan University of Life Sciences, Poland. The publication was financed within the framework of the Polish Ministry of Science and Higher Education's program "Regional Initiative Excellence", in 2019-2022 (No. 005/RID/2018/19)", financing amount PLN 12,000,000.

Institutional Review Board Statement: Ethical review and consent were waived for this study, because despite the fact that it was a human study, it was observational and the study design did not include the ethical issues.

Informed Consent Statement: Informed consent was obtained from all subjects involved in the study.

Data Availability Statement: Data sharing not applicable. The data are not publicly available due to participants privacy.

Conflicts of Interest: The authors declare no conflict of interest.

\section{References}

1. FAO Food and Agriculture Organization of the United Nations. Food Wastage Footprint: Impacts on Natural Resources; Summary Report; Natural Resources Management and Environment Department: Rome, Italy, 2013; Available online: http://www.fao.org/ 3/i3347e/i3347e.pdf (accessed on 24 December 2020).

2. FAO Food and Agriculture Organization. Global Food Losses and Food Waste. 2011. Available online: www.fao.org/3/a-i2697e. pdf (accessed on 23 November 2020).

3. EPA United States Environmental Protection Agency. 2018. Available online: https://www.epa.gov/sustainable-managementfood/sustainable-management-food-basics (accessed on 15 October 2020).

4. NFWS National Food Waste Strategy. Halving Australia's Food Waste by 2030. 2017. Available online: https://www.environment. gov.au/system/files/resources /4683826b-5d9f-4e65-9344-a900060915b1/ files/national-food-waste-strategy.pdf (accessed on 19 November 2020).

5. FUSIONS. 2014. Available online: https://www.eu-fusions.org/index.php/about-food-waste/280-food-waste-definition (accessed on 15 October 2020).

6. European Parliament Resolution of 19 January 2012 on How to Avoid Food Wastage: Strategies for a More Efficient Food Chain in the EU (2011/2175(INI)) (2013/C 227 E/05). Available online: https:/ / eur-lex.europa.eu/legal-content/EN/TXT/PDF/?uri= CELEX:52012IP0014\&from=PL (accessed on 21 September 2020).

7. Kołożyn-Krajewska, D.; Rejman, K.; Gosiewska, M. Marnowanie żywności w Polsce i Europie. Federation of Polish Food Banks Report, Warszawa, 2012. Available online: http://www.niemarnuje.pl/files/sdz_2012_10_16_raport_marnowanie_fpbz.pdf (accessed on 19 November 2020).

8. Parfitt, J.; Barthel, M.; Macnaughton, S. Food waste within food supply chains: Quantification and potential for change to 2050. Phil. Trans. R. Soc. B 2010, 365, 3065-3081. [CrossRef] [PubMed]

9. Rezaei, M.; Liu, B. Food Loss and Waste in the Food Supply Chain. Nutfruit 2017, 26-27. Available online: http://www.fao.org/ 3/a-bt300e.pdf (accessed on 19 November 2020).

10. Göbel, C.; Langen, N.; Blumentha, A.; Teitscheid, P.; Ritter, G. Cutting Food Waste through Cooperation along the food Supply Chain. Sustainability 2015, 7, 1431-1438. [CrossRef]

11. Lipinski, B.; Hanson, C.; Lomax, J.; Kitinoja, L.; Waite, R.; Searchinger, T. Installment 2 of "Creating a Sustainable Food Future" Reducing Food Loss and Waste. World Resources Institute 2013, 1-40. Available online: https://files.wri.org/s3fs-public/ reducing_food_loss_and_waste.pdf (accessed on 19 November 2020).

12. Linh, N.K. Food Waste Management in the Hospitality Industry, Case Study: Clarion Hotel Helsinki; Hagga-Helia University of Applied Sciences: Helsinki, Finland, 2018.

13. Tekin, Ö.A.; Ilyasov, A. The Food Waste in Five-Star Hotels: A Study on Turkish Guests' Attitudes. JOTAGS 2017, 5, 13-31. [CrossRef]

14. Dormer, A.; Finn, D.; Ward, P.; Cullen, J. Carbon footprint analysis in plastics manufacturing. J. Clean. Prod. 2013, 51, 133-141. [CrossRef]

15. Konieczny, P.; Dobrucka, R.; Mroczek, E. Using carbon footprint to evaluate environmental issues of food transportation. Sci. J. Log. 2013, 9, 3-10. 
16. Konieczny, P.; Mroczek, E.; Kucharska, M. Ślad węglowy w zrównoważonym łańcuchu żywnościowym i jego znaczenie dla konsumenta żywności. J. Agribus. Rural Dev. 2013, 3, 51-64.

17. Hoekstra, A. The Water Footprint of Food. 2008. Available online: https://waterfootprint.org/media/downloads/Hoekstra-20 08-WaterfootprintFood.pdf (accessed on 18 November 2020).

18. Hoekstra, A.Y.; Chapagain, A.K.; Aldaya, M.M.; Mekonnen, A.M. Water Footprint Manual. 2009. Available online: https: // waterfootprint.org/media/downloads/WaterFootprintManual2009.pdf (accessed on 19 November 2020).

19. Smith, M.; Love, D.C.; Rochman, C.M.; Neff, R. Microplastics in Seafood and the Implications for Human Health. Curr. Environ. Health Rep. 2018, 5, 375-386. [CrossRef]

20. WRAP Food Surplus and Waste in the UK-Key Facts. 2019. Available online: http://www.wrap.org.uk/sites/files/wrap/ Food\%20Surplus\%20and\%20Waste\%20in\%20the\%20UK\%20Key\%20Facts\%2014\%205\%2019.pdf (accessed on 19 November 2020).

21. Stenmarck, Å.; Jensen, C.; Quested, T.; Moates, G. Estimates of European Food Waste Levels; IVL Swedish Environmental Research Institute: Stockholm, Sweden, 2016; ISBN 978-91-88319-01-2.

22. Federation of Polish Food Banks [FPBŻ] Wasting Food You Waste the Planet Report. Marnując Żywność Marnujesz Planete Raport FPBŻ. 2018. Available online: https:/ /bankizywnosci.pl/wp-content/uploads/2018/10/Przewodnik-do-Raportu_FPBZ_ -Nie-marnuj-jedzenia-2018.pdf (accessed on 21 November 2020).

23. Bräutigam, K.R.; Jörissen, J.; Priefer, C. The extent of food waste generation across EU-27: Different calculation methods and the reliability of their results. Waste Manag Res. 2014, 32, 683-694. [CrossRef]

24. Ocicka, B.; Raźniewska, M. Food waste reduction as a challenge in supply chains management. Sci. J. Logist. 2018, 14, 549-561.

25. Quested, T.; Parry, A. WRAP 2015, Household Food Waste in the UK. Available online: https:/ / www.wrap.org.uk/ sites/files/ wrap/Household_food_waste_in_the_UK_2015_Report.pdf (accessed on 24 September 2020).

26. FUSIONS. 2016. Available online: https://www.eu-fusions.org/index.php/food-service-surplus-solution (accessed on 24 September 2020).

27. Bilska, B.; Grzesińska, W.; Tomaszewska, M.; Rudziński, M. Food waste as an example of ineffective household management. Marnotrawstwo żywności jako przykład nieefektywnego zarządzania w gospodarstwach domowych. Stowarzyszenie Ekonomistów Rolnictwa i Agrobiznesu. Rocz. Nauk. 2015, 17, 4.

28. Silvennoinen, K.; Katajajuuri, J.; Hartikainen, H.; Heikkil, L.; Reinikainen, A. Food waste volume and composition in Finnish households. Brit. Food J. 2014, 116, 1058-1068. [CrossRef]

29. WRAP Finale Report. 2018. Household Food Waste: Restated Data for 2007-2015. Available online: http:/ /www.wrap.org.uk/ sites/files/wrap/Household\%20food\%20waste\%20restated\%20data\%202007-2015.pdf (accessed on 19 November 2020).

30. Van Dooren, C. Supplementary Memorandum, Food Waste in Dutch Households in 2016, Netherlands Nutrition Centre--Honest about Food. 2017. Available online: https://mobiel.voedingscentrum.nl/Assets/Uploads/voedingscentrum/Documents/ Service/English/Supplementary\%20memorandum\%20Food\%20waste\%20in\%20Dutch\%20households\%20in\%202016.pdf (accessed on 21 November 2020).

31. European Comission 2015. Science for Environment Policy, Recycled Plastic Reduces Carbon Footprint of Packaging. Available online: http:/ / ec.europa.eu/environment/integration/research/newsalert/pdf/331na5_en.pdf (accessed on 19 November 2020).

32. Pocol, C.B.; Pinoteau, M.; Amuza, A.; Burlea-Schiopoiu, A.; Glogovet, A.-I. Food waste behavior among Romanian consumers: A cluster analysis. Sustainability 2020, 12, 9708. [CrossRef]

33. Bilska, B.; Tomaszewska, M.; Kołożyn-Krajewska, D. Analysis of the behaviors of Polish consumers in relation to food waste. Sustainability 2020, 12, 304. [CrossRef]

34. Secondi, L.; Principato, L.; Laureti, T. Household food waste behavior in EU-27 countries: A multilevel analysis. Food Policy 2015, 56, 25-40. [CrossRef]

35. Hanssen, O.J.; Syversen, F.; Stø, E. Edible food waste from Norwegian households—Detailed food waste composition analysis among households in two different regions in Norway. Resour. Conserv. Recycl. 2016, 109, 146-154. [CrossRef]

36. Mattar, L.; Abiad, M.G.; Chalak, A.; Diab, M.; Hassan, H. Attitudes and behaviors shaping household food waste generation: Lessons from Lebanon. J. Clean. Prod. 2018, 198, 1219-1223. [CrossRef]

37. Cantaragiu Cantaragiu, R.E. The impact of gender on food waste at the consumer level. Stud. Univ. Vasile Goldis Arad Econ. Ser. 2019, 29, 41-57. [CrossRef]

38. FAO Food and Agriculture Organization of the United Nations. Gender and Food Loss in Sustainable Food Value Chains-A Guiding Note. Rome. 2018. Available online: http:/ / www.fao.org/3/a-I8620EN.pdf (accessed on 19 November 2020).

39. FAO Food and Agriculture Organization of the United Nations. Food Loss and Food Waste. 2020. Available online: http: //www.fao.org/food-loss-and-food-waste/flw-data (accessed on 20 November 2020).

40. Elmenofi, G.A.G.; Capone, R.; Waked, S.; Debs, P.; Bottalico, F.; El Bilali, H. An exploratory survey on household food waste in Egypt. In Proceedings of the VI International Scientific Agriculture Symposium "Agrosym 2015", Jahorina, Bosnia and Herzegovina, 15-18 October 2015; pp. 1298-1304, ISBN 978-99976-632-2-1. [CrossRef]

41. Rohm, H.; Oostindjer, M.; Aschemann-Witzel, J.; Symmank, C.; Almli, V.L.; de Hooge, I.L.; Normann, A.; Karantininis, K. Consumers in a sustainable food supply chain (COSUS): Understanding consumer behavior to encourage food waste reduction. Foods 2017, 6, 104. [CrossRef] 
42. Skotnicka, M.; Karwowska, K.; Gmiechowska, M. The Problem of Food Waste in Different Types of Householdson the Example of the Residents of Poland and Polish People, Residing in the United Kingdom-Pilot Study Scientific Journal Warsaw University of Life Sciences-SGGW. Probl. World Agric. 2018, 18, 282-294.

43. Quested, T.E.; Marsh, E.; Stunell, D.; Parry, A.D. Spaghetti soup: The complex world of food waste behaviours. Res. Conserv. Recycl. 2011, 79, 43-51. [CrossRef]

44. Aschemann-Witzel, J.; De Hooge, I.; Amani, P.; Bech-Larsen, T.; Oostindjer, M. Consumer-Related Food Waste: Causes and Potential for Action. Sustainability 2015, 7, 6457-6477. [CrossRef]

45. Papaj, K.A. Food Waste-Policies, Initiatives and Consumer Behavior. Case Study: Poland and Portugal. Ph.D. Thesis, The NOVA School of Science and Technology (FCT NOVA), Lisbon, Portugal, September 2016. Available online: https:/ /run.unl.pt/ bitstream/10362/20044/1/Papaj_2016.pdf (accessed on 19 November 2020).

46. Jörissen, J.; Priefer, C.; Bräutigam, K.-R. Food waste generation at household level: Results of a survey among employees of two European research centers in Italy and Germany. Sustainability 2015, 7, 2695-2715. [CrossRef]

47. Farr-Wharton, G.; Foth, M.; Choi, J.H.J. Identifying factors that promote consumer behaviors causing expired domestic food waste. J. Consum. Behav. 2014, 13, 393-402. [CrossRef]

48. Dusoruth, V.; Peterson, H.H. Food waste tendencies: Behavioral response to cosmetic deterioration of food. PLoS ONE 2020, 15, e0233287. [CrossRef] [PubMed]

49. Helmert, J.R.; Symmank, C.; Pannasch, S.; Rohm, H. Have an eye on the buckled cucumber: An eye tracking study on visually suboptimal foods. Food Qual. Prefer. 2017, 60, 40-47. [CrossRef]

50. Yildirim, H.; Capone, R.; Karanlik, A.; Bottalico, F.; Debs, P.; Bilali, H. Food wastage in Turkey: An exploratory survey on household food waste. J. Food Nutr. Res. 2016, 4, 1.

51. Fami, H.S.; Aramyan, L.H.; Sijtsema, S.J.; Alambaigi, A. Determinants of household food waste behavior in Tehran city: A structural model. Resour. Conserv. Recycl. 2019, 143, 154-166. [CrossRef]

52. Glanz, R. Causes of Food Waste Generation in Households-An Empirical Analysis. Master's Thesis, University of Natural Resources and Applied Life Sciences, Vienna, Austria, 2008.

53. Koivupuro, H.-K.; Hartikainen, H.; Silvennoinen, K.; Katajajuuri, J.-M.; Heikintalo, N.; Reinikainen, A.; Alkanen, L. Influence of socio-demographical, behavioral and attitudinal factors on the amount of avoidable food waste generated in Finnish households. Int. J. Consum. Stud. 2012, 36, 183-191. [CrossRef]

54. Williams, H.; Wikström, F.; Otterbring, T.; Löfgren, M.; Gustavsson, A. Reasons for household food waste with special attention to packaging. J. Clean. Prod. 2012, 24, 141-148. [CrossRef]

55. Aschemann-Witzel, J. Consumer perception and preference for suboptimal food under the emerging practice of expiration date based pricing in supermarkets. Food Qual. Prefer. 2018, 63, 119-128. [CrossRef] 